\title{
How Interdisciplinary Teams Can Create Multidisciplinary Education: On the Interplay Between Team Processes and Educational Quality
}

Citation for published version (APA):

Stalmeijer, R. E., Gijselaers, W. H., Wolfhagen, H. A. P., Scherpbier, A. J. J. A., \& Harendza, S. (2007). How Interdisciplinary Teams Can Create Multidisciplinary Education: On the Interplay Between Team Processes and Educational Quality. Medical Education, 41(11), 1059-1066. https://doi.org/10.1111/j.13652923.2007.02898.x

Document status and date:

Published: 01/01/2007

DOI:

10.1111/j.1365-2923.2007.02898.x

Document Version:

Publisher's PDF, also known as Version of record

Please check the document version of this publication:

- A submitted manuscript is the version of the article upon submission and before peer-review. There can be important differences between the submitted version and the official published version of record.

People interested in the research are advised to contact the author for the final version of the publication, or visit the DOI to the publisher's website.

- The final author version and the galley proof are versions of the publication after peer review.

- The final published version features the final layout of the paper including the volume, issue and page numbers.

Link to publication

\footnotetext{
General rights rights.

- You may freely distribute the URL identifying the publication in the public portal. please follow below link for the End User Agreement:

www.umlib.nl/taverne-license

Take down policy

If you believe that this document breaches copyright please contact us at:

repository@maastrichtuniversity.nl

providing details and we will investigate your claim.
}

Copyright and moral rights for the publications made accessible in the public portal are retained by the authors and/or other copyright owners and it is a condition of accessing publications that users recognise and abide by the legal requirements associated with these

- Users may download and print one copy of any publication from the public portal for the purpose of private study or research.

- You may not further distribute the material or use it for any profit-making activity or commercial gain

If the publication is distributed under the terms of Article 25fa of the Dutch Copyright Act, indicated by the "Taverne" license above, 


\title{
How interdisciplinary teams can create multi-disciplinary education: the interplay between team processes and educational quality
}

\author{
Renee E Stalmeijer, ${ }^{1}$ Wim H Gijselaers, ${ }^{2}$ Ineke H A P Wolfhagen, ${ }^{1}$ Sigrid Harendza ${ }^{3}$ \& \\ Albert J J A Scherpbier ${ }^{4}$
}

CONTEXT Many undergraduate medical education programmes offer integrated multi-disciplinary courses, which are generally developed by a team of teachers from different disciplines. Research has shown that multi-disciplinary teams may encounter problems, which can be detrimental to productive co-operation, which in turn may diminish educational quality. Because we expected that charting these problems might yield suggestions for addressing them, we examined the relationships between team diversity, team processes and course quality.

METHODS We administered a questionnaire to participants from 21 interdisciplinary teams from 1 Dutch and 1 German medical school, both of which were reforming their curriculum. An adapted questionnaire on team learning behaviours, which had been validated in business contexts, was used to collect data on team processes, team learning behaviours and diversity within teams. We examined the relationship between the team factors and educational quality measures of the courses designed by the teams.

RESULTS A total of 84 teachers $(60 \%)$ completed the questionnaire. Bivariate correlation analysis

\footnotetext{
${ }^{1}$ Department of Educational Development and Research, Faculty of Health, Medicine and Life Sciences, Maastricht University, Maastricht, The Netherlands

${ }^{2}$ Department of Educational Development and Research, Faculty of Economics and Business Administration, Maastricht University, Maastricht, The Netherlands

${ }^{3}$ University Medical Centre Hamburg-Eppendorf, Hamburg, Germany ${ }^{4}$ Institute for Medical Education, Faculty of Health, Medicine and Life Sciences, Maastricht University, Maastricht, The Netherlands

Correspondence: Renee E Stalmeijer, Department of Educational Development and Research, Faculty of Health, Medicine and Life Sciences, Maastricht University, PO Box 616, 6200 MD Maastricht, The Netherlands. Tel: 003143388 5735; Fax: 003143388 5779;

E-mail: r.stalmeijer@educ.unimaas.nl
}

showed that several aspects of diversity, conflict, working climate and learning behaviour were correlated with course quality.

CONCLUSIONS The negative effects of the diversity measures, notably, value diversity, on other team processes and course quality and the positive association between psychological safety and team learning suggest that educational quality might be improved by enhancing the functioning of multi-disciplinary teams responsible for course development. The relationship between team processes and educational quality should be studied among larger study populations. Student ratings should also be considered in measuring educational quality.

KEYWORDS multicentre study [publication type]; *questionnaires; Netherlands; Germany; education, medical, undergraduate/*organisation \& administration; curriculum; interprofessional relations; teaching/*methods; *group processes.

Medical Education 2007: 41: 1059-1066

doi:10.1111/j.1365-2923.2007.02898.x

\section{INTRODUCTION}

It is the task of medical schools to equip their graduates with appropriate knowledge, skills and attitudes, while taking into account resource constraints, government regulations and academic and professional views regarding the required competencies. ${ }^{1}$ In order to improve the learning of students, innovative educational approaches have been introduced, such as outcomes-based, integrated and community-based programmes, ${ }^{2-4}$ all of which 


\section{Overview}

What is already known on this subject

Undergraduate medical curricula are becoming increasingly multi-disciplinary as a result of curricular reforms. Research and practice inform us that it is not self-evident that effective collaboration will be achieved by multi-disciplinary course development teams consisting of faculty from different departments.

\section{What this study adds}

This study contributes insight into processes and factors that either stimulate or debilitate collaboration within multi-disciplinary teacher teams on educational development.

\section{Suggestions for further research}

The nature of the relationship between team processes and the quality of education should be further investigated in studies among larger numbers of teams. Student ratings of educational quality should be incorporated as an output measure.

involve the integration of clinical and basic sciences in order to offer relevant and stimulating learning experiences to students. Integrative perspectives on medical education are based on the premise that multi-disciplinary knowledge is functional to the understanding and learning of medical problems as encountered in medical practice. ${ }^{5}$

Courses in a multi-disciplinary curriculum are generally designed and delivered by multi-disciplinary teams of experts from the contributing disciplines. The sharing and exchange of knowledge, expertise and educational experience in multi-disciplinary teams can be a complicated process, ${ }^{6}$ which is vulnerable to various adverse influences. There may be a detrimental effect on team outcomes when professionals from different backgrounds hold divergent values concerning task performance and teamwork. ${ }^{7}$ Background diversity in multi-disciplinary teams has been shown not to enhance creativity and problem solving, ${ }^{8,9}$ and the individual's performance as a team member may fall short of his or her customary solo performance.

Studies in various professional domains have reported associations between the diversity of team members' professional backgrounds and a consistent set of processes differentiating between productive and unproductive teams. ${ }^{10}$ Important factors in the interplay between diversity and team performance, reported in management settings, have included not only individual characteristics, such as departmental position, professional background, age, gender and nationality, but also team culture and climate, and team processes, such as managing potential conflict, building a climate of trust, developing a shared vision of goals, creating a positive learning climate, and coordination of work processes. ${ }^{9-11}$ Poor team communication was shown to be a cause of tension in multi-professional operating room teams and also of increased risk for surgical patients. ${ }^{12}$ Factors in the organisation at large affect team processes as well. Support from leaders outside the team was reported to be beneficial, ${ }^{6}$ whereas '....rigid specialisation, departmental isolationism, and competition between the research and service mission...' were disadvantageous to good team performance. ${ }^{4}$

However, the most powerful effects on multi-disciplinary team performance appear to reside within teams' collaborative processes and learning behaviours. Numerous studies have revealed that conflict management, willingness to learn, capacity to build a climate of trust, cohesion and psychological safety were key to team performance. ${ }^{8,9,13-16}$

\section{A THEORETICAL FRAMEWORK FOR MULTI-DISCIPLINARY TEAM PRODUCTIVITY}

Many studies have focused on isolated team characteristics. Because this paints only a partial picture of the relationship between team characteristics and team performance, Van den Bossche et al. ${ }^{6}$ developed a comprehensive team model. ${ }^{4}$ This model has been validated in settings ranging from student teams to teams in business settings ${ }^{6,17}$ (Fig. 1). We used this model to examine teamwork concerning curriculum development in undergraduate medical education. Van den Bossche's model is based on a review of team diversity research and incorporates the relationships between team members' background characteristics and team process variables that may affect team performance. 
Figure 1 Team process model that is explored in this study (based on Van den Bossche et al. and Van Gennip et al.). PBL = problem-based learning

\section{Team diversity}

The model distinguishes 3 types of diversity: ${ }^{8}$

1 informational diversity (e.g. related to functional and educational background);

2 social category diversity (e.g. gender, age, ethnicity), and

3 value diversity, defined as '.. a difference in opinion concerning what group members think the group's real task, goals, target or mission should be'. ${ }^{8}$

Greater diversity has shown a tendency to increase the likelihood of debilitating conflict within teams. ${ }^{10}$

\section{Team diversity and team conflict}

Various studies, including studies in hospital settings, have demonstrated that diversity may be more conducive to conflict than to effective teamwork. ${ }^{18}$

\section{Team diversity and working climate}

Team diversity has been reported to cause in-group, out-group bias', ${ }^{19}$ characterised by members labelling each other as similar or dissimilar to themselves with a concomitant increased risk of conflict as a result of perceived dissimilarity and persons feeling less 'safe' in the presence of other team members. Another study ${ }^{9}$ identified 'psychological safety' as the shared belief among team members that the team was safe for interpersonal risk taking. Van der Vegt $e t a l .{ }^{13}$ used the term 'interdependence' with reference to the relationship between team members' beliefs about each other and the team's task performance, distinguishing between task interdependence, related to single activities, and outcome interdependence, related to team members'

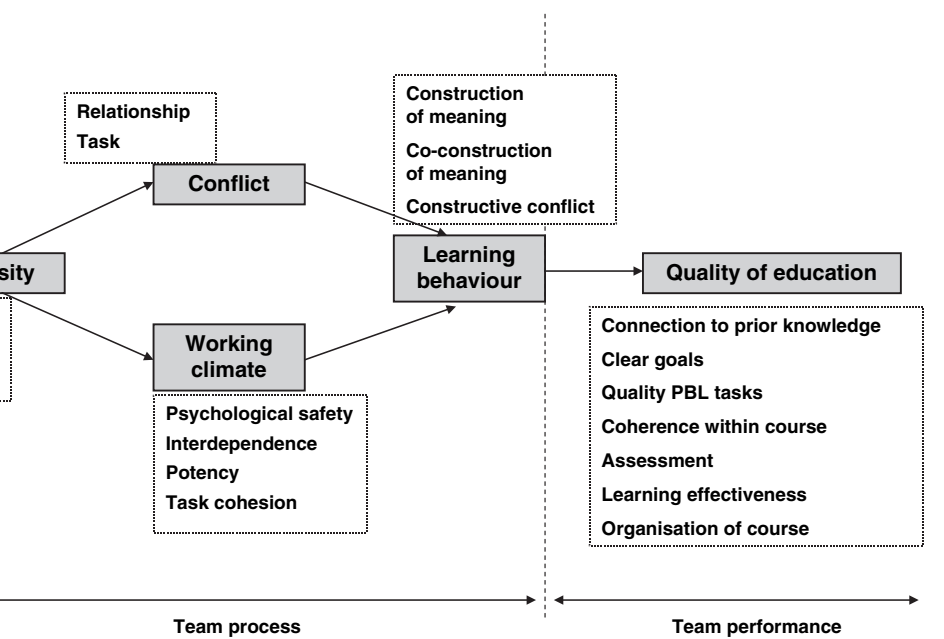

perceived need for contributions from other members. Another concept affecting the working climate is 'group potency', that is, the team's beliefs regarding their capacity to deal with tasks. This was identified in a study which showed team success to be unlikely if the team felt it was no use making the effort. ${ }^{20} \mathrm{~A}$ related belief, identified by Beal et al. ${ }^{19}$ is 'task cohesion', which refers to the shared commitment by the team to achieve goals requiring group effort.

\section{Learning behaviour of the team and team performance}

Teams can only achieve their full potential if they succeed in harnessing their members' knowledge, expertise and experience to enhance team performance. ${ }^{16}$. This process has been qualified as teamlearning behaviour ${ }^{6}$ and comprises 3 elements:

1 construction of meaning;

2 co-construction of meaning, and

3 constructive conflict.

Construction of meaning occurs when a team discussion culminates in a shared concept of a certain situation. Co-construction of meaning occurs when team members arrive at a more profound understanding of a subject through interpreting, questioning and paraphrasing the various contributions to the team discussion. Constructive conflict originates from '... a perceived contradiction between the individual's existing understanding and what the individual experiences'. ${ }^{16}$

To our knowledge, the issue of relationship between team processes in multi-disciplinary course planning groups in medical education and the effectiveness of these groups in terms of the courses they designed, have not been addressed in the domain of 
undergraduate medical education, although medical curricula have been offering multi-disciplinary courses for quite some time. We investigated the relationships between team characteristics, team processes and team effectiveness in 2 medical schools, both engaged in multi-disciplinary curriculum development. Although they shared a multidisciplinary approach to education, the 2 schools had different histories of curriculum development.

\section{METHODS}

\section{Team learning behaviour}

\section{Participants}

Members from 21 multi-disciplinary teams, engaged in course design in a German (school A) and a Dutch (school B) medical school participated in this study. The 2 schools were at different stages in the development and implementation of a new undergraduate medical curriculum characterised by multi-disciplinary education and problem-based learning (PBL). The members of the teams differed substantially in profession (doctor, basic scientist, social scientist), experience with educational development, gender, marital status, and age. Each team was responsible for the design, organisation and delivery of 1 multidisciplinary course. In school A, 49 team members in 6 teams, consisting of 7-10 members per team, were responsible for clinical courses in Years 3-5 of the 6-year curriculum. In school B, 90 team members in 15 teams of 4-10 members per team designed courses for Years 1-3 in which basic science and clinical topics were integrated.

\section{Instrument}

We collected data about diversity, conflict, working climate and learning behaviour in multi-disciplinary, course-planning teams by administering the Team Learning Behaviour Questionnaire (TLBQ), which is based on the model described in the Introduction. It had been tested in business and higher education environments. ${ }^{4,5}$ The version used in this study consists of the questionnaire developed by Van den Bossche $e t a l .{ }^{6}$ with some additions by Van Gennip et al. ${ }^{17}$ We adapted the TLBQ to the medical education context by, for example, changing the question on team diversity from 'How many years have you worked in this management team?' to 'How many years have you been involved in this course-planning group?' The TLBQ requires respondents to rate their agreement with 50 statements concerning teamwork on a 5-point Likert scale $(1=$ totally disagree; $5=$ totally agree). For example, psychological safety was measured by responses to the statement: 'When I make a mistake in this teacher team, it is often held against me.'

\section{Procedure}

All the team members received a letter inviting them to complete the questionnaire and return it by post. They were told by the course and/or curriculum coordinators that the study was important and that the data would be treated confidentially. The data were anonymised and could not be traced back to individual respondents. Two weeks after the first invitation, a reminder was sent to non-responders. Refusal to participate after this reminder was recorded as non-response. Ethical approval was not sought, because this was not deemed necessary by the ethical review boards of either school.

\section{Analyses of diversity and the TLBQ}

We used the following mathematical equation proposed by Teachman, ${ }^{20}$ which is frequently used in diversity research ${ }^{21}$ as a measure of the informational and social category diversity within teams:

$$
\text { Diversity }=\sum(-(\mathrm{P}(\ln \mathrm{P})) \text {, }
$$

where $\mathrm{P}$ is the proportion of team members who have a diversity characteristic. If a characteristic is not present in a team, it is given a value of 0 . The higher the diversity index, the greater the distribution of characteristics in a team. ${ }^{17}$ For informational diversity, we considered educational background, function within the team (coordinator or member), number of years on the team, and number of years with the organisation. For social category diversity, we considered age, gender, marital status, number of children and nationality.

spss Version 13.0 was used for all analyses. The alpha coefficients of the different factors of the TLBQ are presented in Table 3. For further analysis, the item results were first aggregated at factor level. Because of the exploratory nature of this study, bivariate correlation analyses were used to explore the relationships between the factors in the team processes.

\section{Team performance: educational quality}

We determined educational quality by asking medical education experts and course coordinators involved 
in the development of the curricula to complete an evaluation list containing variables relating to course quality. ${ }^{22}$ We developed this list on the basis of the literature on (medical) curriculum evaluation. ${ }^{23}$ It consisted of 5 major topics: educational goals; educational content; teaching and learning; assessment, and curriculum organisation. For each topic, several items had to be answered on a 5-point Likert scale. Comments on the list from a medical education expert led to some modifications in item content and wording. In school $\mathrm{B}$, the list was completed by the coordinator of Years 1 and 2, the coordinator of Year 3, and the person responsible for quality improvement in the medical curriculum. Together they formed a peer review committee for the course development teams. They responded favourably to our invitation to participate in the research. They received a booklet with an explanatory letter and 15 copies of the evaluation list, 1 for each course to be rated, which they were asked to complete and return to the researchers. In school B the interdisciplinary curriculum had been in place for some time but the interdisciplinary curriculum in school A was still under development, so it was impossible for anyone to have formed a comprehensive picture of it based on experience. Because of this, we asked the course coordinators to evaluate the courses developed by their respective teams (self-evaluation). Each course had 2 course coordinators and they were each asked to evaluate their course. All the course coordinators received an evaluation list from a member of the curriculum committee. The completed evaluation lists were returned to the researchers by post.

\section{Analyses of team learning behaviour and team performance}

SPSs 13.0 was used to analyse the data on team learning behaviour and team performance. The data were aggregated at team level because the analysis was performed at team level. Bivariate correlation analysis was performed to explore the relationships between the variables concerning team learning behaviour and the different aspects of team performance.

\section{RESULTS}

\section{Response}

A total of 84 participants completed and returned the TLBQ, giving a response rate of $60 \%$. At least 2 members responded from each teacher team and the number of respondents per team varied between 2 and 8 (Table 1).

In school $\mathrm{B}$, the 3 members of the peer review committee evaluated 15 courses each. In school A, each of the 12 course coordinators evaluated their own course, so that a total of 6 courses were evaluated.

\section{Diversity index}

The overall social category diversity was 0.567 . The overall informational diversity was 0.615 . Both measures were higher in school B than in school A (Table 2).

\section{Bivariate correlation analysis}

Diversity and conflict

Value diversity was related to increased relationship conflict $(r=0.65, P<0.01)$ and diminished task conflict $(r=-0.54, P<0.05)$. Task conflict correlated negatively with relationship conflict $(r=-0.69$, $P<0.01)$.

\section{Diversity and working climate}

Value diversity was negatively related to all factors concerning working climate. Social category diversity showed positive correlations with group potency $(r=0.51, P<0.05)$.

Table 1 Responses to the questionnaire

Number of completed questionnaires

Germany

Netherlands

Total

$\mathrm{SD}=$ standard deviation

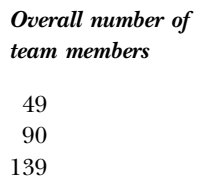

Response

percentage

Number of

65

58

60 responding teams

6

15

21

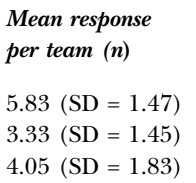

Mean response

$5.83(\mathrm{SD}=1.47)$

$4.05(\mathrm{SD}=1.83)$ 
Table 2 Proportion of diversity in the teams

$\begin{array}{llll} & \text { Overall } & \begin{array}{l}\text { Average team } \\ \text { proportion } \\ \text { Pchool A }\end{array} & \text { School B } \\ & & & \\ \text { Social category diversity } & 0.567 & 0.391 & 0.607 \\ \text { Informational diversity } & 0.615 & 0.520 & 0.653 \\ \text { Diversity }=\Sigma(-[\mathrm{P}(\ln \mathrm{P}]) & & & \end{array}$

\section{Conflict and learning behaviour}

Task conflict was positively related to constructive conflict $(r=0.47, P<0.05)$ and relationship conflict was negatively related to construction of meaning $(r=-0.52, P<0.05)$.

\section{Working climate and learning behaviour}

All aspects of working climate were positively related to team learning behaviour. Psychological safety, in particular, showed a positive relationship with all aspects of team learning behaviour.

Team processes and educational quality: self-appraisal by course coordinators (school A)

Correlation analysis of all aspects of team process and all aspects of educational quality for school A showed that clarity of course goals and course organisation were related to team processes. Social category diversity $(r=-0.90, P<0.05)$ and value diversity $(r=-0.83, P<0.05)$ correlated negatively with the clarity of the course goals formulated by the team, which in turn was positively correlated with task cohesion $(r=0.85, P<0.05)$ and co-construction of meaning $(r=0.94, P<0.01)$. There was a positive correlation between course organisation and task conflict $(r=0.86, P<0.05)$, task cohesion $(r=0.97, P<0.05)$, and co-construction of meaning $(r=0.88, P<0.05)$. Course organisation was negatively correlated with diversity of social category $(r=-0.82, P<0.05)$ and

Table 3 Bivariate correlation matrix; team processes and educational quality

\begin{tabular}{|c|c|c|c|c|c|c|c|c|c|c|c|c|}
\hline Variable $+($ alpha coefficient $)$ & 1 & 2 & 3 & 4 & 5 & 6 & 7 & 8 & 9 & 10 & 11 & 12 \\
\hline \multicolumn{13}{|l|}{ Team processes } \\
\hline \multicolumn{13}{|l|}{ Diversity } \\
\hline 1 Social category diversity & 1.00 & & & & & & & & & & & \\
\hline 2 Informational diversity & 0.22 & 1.00 & & & & & & & & & & \\
\hline 3 Value diversity $(\mathbf{0 . 8 7})$ & -0.23 & -0.39 & 1.00 & & & & & & & & & \\
\hline \multicolumn{13}{|l|}{ Conflict } \\
\hline 4 Task conflict $(\mathbf{0 . 7 5 )}$ & -0.07 & 0.32 & $-0.54^{*}$ & 1.00 & & & & & & & & \\
\hline 5 Relational conflict $(\mathbf{0 . 8 4})$ & -0.23 & $-0.46^{*}$ & $0.65 \dagger$ & $-0.69 \dagger$ & 1.00 & & & & & & & \\
\hline \multicolumn{13}{|l|}{ Working climate } \\
\hline 6 Task cohesion $(\mathbf{0 . 7 4})$ & 0.36 & 0.24 & $-0.67 \dagger$ & $0.61 \dagger$ & $-0.55 \dagger$ & 1.00 & & & & & & \\
\hline 7 Psychological safety (0.70) & 0.33 & 0.06 & $-0.44^{*}$ & 0.41 & -0.26 & $0.53^{*}$ & 1.00 & & & & & \\
\hline 8 Potency $(\mathbf{0 . 8 5})$ & $0.51^{*}$ & 0.04 & $-0.70 \dagger$ & 0.25 & $-0.50 *$ & $0.56 \dagger$ & 0.24 & 1.00 & & & & \\
\hline 9 Interdependence $\mathbf{( 0 . 6 6 )}$ & 0.43 & 0.09 & $-0.68 \dagger$ & 0.43 & $-0.62 \dagger$ & $0.44^{*}$ & $0.45^{*}$ & $0.70 \dagger$ & 1.00 & & & \\
\hline \multicolumn{13}{|l|}{ Learning behaviour } \\
\hline 10 Construction of meaning $(\mathbf{0 . 8 7})$ & 0.29 & 0.27 & $-0.78 \dagger$ & 0.38 & $-0.52 *$ & $0.66 \dagger$ & $0.65 \dagger$ & $0.48^{*}$ & $0.55^{*}$ & 1.00 & & \\
\hline 11 Co-construction of meaning $(\mathbf{0 . 8 3})$ & 0.30 & -0.05 & $-0.62 \dagger$ & 0.37 & -0.36 & $0.63 \dagger$ & $0.72 \dagger$ & $0.56 \dagger$ & $0.65 \dagger$ & $0.60 \dagger$ & 1.00 & \\
\hline 12 Constructive conflict $(\mathbf{0 . 8 3})$ & 0.12 & -0.04 & $-0.54^{*}$ & $0.47 *$ & -0.32 & $0.62 \dagger$ & $0.68 \dagger$ & $0.44^{*}$ & $0.63 \dagger$ & $0.57 *$ & $0.85 \dagger$ & 1.00 \\
\hline \multicolumn{13}{|c|}{ Self-judgement quality of education (organisation A) } \\
\hline 13 Linkage to prior knowledge & 0.18 & 0.09 & 0.15 & 0.04 & -0.28 & -0.40 & 0.41 & -0.32 & -0.42 & -0.08 & 0.03 & -0.02 \\
\hline 14 Coherence within course & 0.14 & -0.27 & 0.25 & 0.38 & -0.26 & 0.43 & 0.05 & 0.15 & -0.27 & -0.28 & 0.48 & 0.71 \\
\hline 15 Clearness of course goals & $-0.90 *$ & 0.12 & $-0.83^{*}$ & 0.75 & -0.76 & $0.85^{*}$ & 0.20 & 0.45 & 0.59 & 0.72 & $0.94 \dagger$ & 0.81 \\
\hline 16 Assessment & -0.31 & -0.32 & 0.04 & -0.12 & -0.03 & 0.18 & $0.86^{*}$ & -0.35 & -0.17 & 0.55 & 0.46 & 0.64 \\
\hline 17 Organisation & $-0.82 *$ & 0.48 & -0.69 & $0.86 *$ & $-0.91^{*}$ & $0.97 \dagger$ & 0.26 & 0.16 & 0.17 & 0.63 & $0.88^{*}$ & 0.74 \\
\hline 18 Learning effectiveness & -0.38 & -0.08 & 0.02 & 0.01 & -0.15 & 0.33 & $0.86^{*}$ & -0.45 & -0.31 & 0.59 & 0.50 & 0.66 \\
\hline 19 Quality of PBL tasks & 0.03 & -0.60 & 0.15 & -0.48 & -0.24 & -0.35 & 0.80 & -0.30 & -0.04 & 0.32 & 0.08 & 0.19 \\
\hline \multicolumn{13}{|c|}{ Expert-judgement quality of education (organisation B) } \\
\hline 20 Linkage to prior knowledge & 0.03 & -0.44 & 0.00 & -0.05 & 0.02 & 0.07 & 0.10 & 0.18 & 0.15 & -0.08 & 0.06 & 0.12 \\
\hline 21 Coherence within course & -0.11 & $-0.54 *$ & -0.24 & 0.14 & -0.08 & 0.07 & 0.11 & 0.29 & 0.19 & 0.12 & 0.26 & 0.09 \\
\hline 22 Clearness course goals & 0.12 & -0.13 & -0.33 & 0.20 & -0.36 & 0.18 & 0.42 & 0.51 & 0.29 & 0.27 & 0.36 & 0.12 \\
\hline 23 Assessment & -0.25 & -0.38 & 0.10 & 0.11 & -0.33 & -0.26 & 0.03 & 0.09 & 0.14 & 0.02 & 0.24 & 0.10 \\
\hline 24 Organisation & -0.06 & -0.13 & -0.42 & $0.55^{*}$ & -0.45 & 0.28 & 0.41 & 0.30 & 0.23 & 0.31 & 0.46 & 0.26 \\
\hline 25 Learning effectiveness & 0.06 & -0.48 & 0.09 & -0.41 & 0.41 & -0.01 & -0.07 & 0.28 & -0.18 & 0.09 & -0.18 & -0.23 \\
\hline 26 Quality of PBL tasks & -0.24 & $-0.52 *$ & -0.05 & -0.08 & 0.03 & -0.15 & 0.00 & 0.27 & 0.02 & 0.02 & 0.03 & -0.02 \\
\hline
\end{tabular}

$* P<0.05$ (2-tailed) $\dagger P<0.01$ (2-tailed)

$\mathrm{PBL}=$ problem-based learning 
relational conflict $(r=-0.91, P<0.05)$. Psychological safety showed a positive correlation with the quality of assessment $(r=0.86, P<0.05)$ and the educational effectiveness of a course $(r=0.86$, $P<0.05)$.

Team process and educational quality: expert judgement by peers (school B)

In organisation $\mathrm{B}$, informational diversity was negatively related to both internal course coherence $(r=-0.54, P<0.05)$ and the quality of PBL tasks designed for a course $(r=-0.52, P<0.05)$. In both schools, task conflict was positively correlated with course organisation (A: $r=0.86, P<0.86$; B: $r=0.55$, $P<0.55)$.

Table 3 shows the results of the bivariate correlation analyses.

\section{CONCLUSIONS AND IMPLICATIONS}

The connections between measures of team processes and measures of educational quality that were found in both schools appear to confirm the results of earlier team studies. ${ }^{7}$ The most striking finding is that measures of team diversity, value diversity in particular, are positively related to relational conflict but negatively to task conflict, and negatively related to other team processes (such as measures of working climate and learning behaviour) as well as to educational quality (such as the clarity of course goals in both schools, course organisation in school A, and course coherence in school B). The relationship between value diversity and relational conflict suggests that collaboration within a team consisting of members with different values and experience may complicate relations within the team. That this has repercussions for team functioning and course quality is suggested firstly by the negative correlations between relational conflict and the working climate and learning behaviour in the team as well as the organisation of the course.

The team process variables other than the diversity measures showed numerous mutual relationships, suggesting positive relationships between psychological safety and team learning, in addition to the adverse effects of relational conflict. This appears to confirm results from earlier studies that a climate of mutual trust is a prerequisite for successful learning in a team environment. ${ }^{9}$
The results also appear to confirm that excellent individual performances by teachers are not necessarily maintained when these teachers are part of a team and that team performance may be strongly influenced by diversity features of individual members, the presence or lack of mutual trust, and the presence of different types of conflict. Whether the team succeeds in producing a good course is related to whether the processes within the team are conducive to team learning.

The marked effects of the team processes suggest that it may be worthwhile for medical schools to invest in measures to facilitate group productivity in teams designing a multi-disciplinary curriculum. ${ }^{24}$ The findings with regard to value diversity and lack of trust within the teacher teams suggest that it is important to identify preconditions that can be expected to promote effective team functioning. The organisation as a whole, and course coordinators in particular, might focus on fostering a shared vision, goals and values in relation to educational development tasks given to the block planning groups to ensure that team members start off on an equal footing.

A limitation of our study is that it included only a moderate number of participating course development teams $(n=21)$. Nevertheless, we found clear indications of effects of team processes that warrant further investigation of the relations between team processes and educational quality in more teams and a wider area of courses and organisations. Such studies might also include a wider range of educational outcome measures, such as assessment results and student evaluations of courses.

However, the main outcome of this study seems to be that medical schools should actively take steps to foster good team practices to enhance the quality delivered by teams designing multi-disciplinary courses.

Contributors: RES was the principal investigator, performed the data analysis and wrote the paper. WHG, IHAPW, SH and AJJAS made comments and suggestions for improvement. SH and AJJAS contributed to the data collection. All authors meet the criteria for authorship. Acknowledgements: The authors would like to thank Mereke Gorsira for her help in editing this article.

Funding: None.

Conflicts of interest: None.

Ethical approval: $\quad$ Ethical approval was not sought. 


\section{REFERENCES}

1 Meyer J, Land R Threshold concepts and troublesome knowledge: linkages to ways of thinking and practising within the disciplines. ETL Project. Occasional Report 4. 2003. http://www.ed.ac.uk/etl/publications.html. [Accessed 12 December 2005.]

2 O'Neill PA, Morris J, Baxter CM. Evaluation of an integrated curriculum using problem-based learning in a clinical environment: the Manchester experience. Med Educ 2000;34 (3):222-30.

3 Newble D, Stark P, Bax N, Lawson M. Developing an outcome-focused core curriculum. Med Educ 2005;39 (7):680-7.

4 Chatterjee N. Infusing the interdisciplinary into medical/health sciences education: vitamins or vaccines? Med Educ Online 2002 [serial online] 2002;7 (3) URL: http://www.med-ed-online.org.

5 McGuire CH. Contributions and challenges of medical education research. Acad Med 1996;71 (10):121-6.

6 Van den Bossche P, Gijselaers WH, Segers MSR, Kirschner PA. Social and cognitive factors driving teamwork in collaborative learning environments: team learning beliefs and behaviours. Small Group Res 2006;37 (5):490-521.

7 Van den Bossche P. Minds in teams. The influence of social and cognitive factors on team learning.PhD Thesis.Maastricht: Maastricht University 2006.

8 Jehn KA, Northcraft GB, Neale MA. Why differences make a difference: a field study of diversity, conflict, and performance in workgroups. $\operatorname{Adm} \operatorname{Sci} Q$ 1999;44:741-63.

9 Edmondson A. Psychological safety and learning behaviour in work teams. Adm Sci Q 1999;44:350-83.

10 De Dreu CKW, Weingart LR. Task versus relationship conflict, team performance, and team member satisfaction: a meta-analysis. J Appl Psychol 2003;88 (4): 741-9.

11 Mohammed S, Ringseis E. Cognitive diversity and consensus in group decision making: the role of inputs, processes and outcomes. Organ Behav Hum Decis Process 2001;85 (2):310-35.

12 Tucker A, Edmondson A. Why hospitals don't learn from failures: organisational and psychological dynamics that inhibit system change. Calif Manage Rev 2003;4 (7):55-72.
13 Van der Vegt G, Emans B, Van der Vliet E. Motivating effects of task and outcome interdependence in work teams. Group Organ Manage 1998;23 (2):124-43.

14 Van Knippenberg D, De Dreu CKW, Homan AC. Work group diversity and group performance: an integrative model and research agenda. J Appl Psychol 2004;89 (6):1008-22.

15 Roschelle J. Learning by collaborating: convergent conceptual change. J Learning Sci 1992;2 (3):235-76.

16 Webb NM, Palincsar AS. Group processes in the classroom. In: Berliner DC, Calfee RC, eds. Handbook of Educational Psychology. New York: Prentice Hall International 1996;841-73.

17 Van Gennip AE, Gijselaers WH, Van de Wiel MWJ. Team learning: dealing with diversity. The influence of diversity in teams on team processes and performance. Master Thesis.Maastricht: Maastricht University 2004.

18 Lingard L, Reznick R, Espin S, Regehr G, DeVito I. Team communication in the operating room: talk patterns, sites of tension, and implications for novices. Acad Med 2002;77 (3):232-7.

19 Beal DJ, Cohen RR, Burke MJ, McLendon CL. Cohesion and performance in groups: a meta-analysis clarification of construct relations. J Appl Psychol 2003;88 (6):989-1004.

20 Teachman JD. Analysis of population diversity. Sociol Methods Res 1980;8:341-62.

21 Schippers MC. Diversity and team outcomes: the moderating effects of outcome interdependence and group longevity and the mediating effect of reflexivity. J Organ Behav 2003;24:779-802.

22 Dolmans DHJM, Wolfhagen HAP, Scherpbier AJJA. From quality assurance to total quality management: how can quality assurance result in continuous improvement in health professions education? Educ Health 2003;16 (2):210-7.

23 Prideaux D. ABC of learning and teaching in medicine curriculum design. BMJ 2003;326:268-70.

24 Bland CJ, Center BA, Finstad DA, Risbey KR, Staples JG. A theoretical, practical, predictive model of faculty and department research productivity. Acad Med 2005;80 (3):225-37.

Received 23 October 2006; editorial comments to authors 26 February 2007; accepted for publication 2 July 2007 